\title{
FAKTOR-FAKTOR YANG MEMPENGARUHI KEPATUHAN WAJIB PAJAK DALAM MEMBAYAR PAJAK MOBIL DENGAN DIBERLAKUKANNYA PAJAK PROGRESIF DI KOTA SURAKARTA
}

\author{
Danarsi $^{1}$, Siti Nurlaela ${ }^{2}$, Hendro Subroto ${ }^{3}$ \\ Fakultas Ekonomi, Progam Studi Akuntansi Universitas Islam Batik Surakarta \\ E-mail:diswarsa@yahoo.com
}

\begin{abstract}
ABSTRAK
Penelitian ini bertujuan menganalisis pengaruh pemahaman, tarif pajak, kualitas pelayanan, kesadaran perpajakan, sanksi perpajakan terhadap kepatuhan wajib pajak dalam membayar pajak mobil dengan diberlakukannya pajak progresif di kota Surakarta. Penelitian ini menggunakan pendekatan survey lapangan (field research) melalui kuesioner yang di sampaikan kepada wajib pajak mobil di Kota Surakarta. Responden penelitian adalah wajib pajak kendaraan bermotor yang membayar pajak di SAMSAT Surakarta.Sampelnya adalah wajib pajak mobil yang dikenakan tarif pajak progresif .Teknik pengambilan sampel menggunakan Random Sampling dengan sampel penelitian sebanyak 30 responden. Metode analisis data menggunakan uji regresi linear berganda. Hasil penelitian ini menunjukan bahwa: Pemahaman dan Kesadaran perpajakan tidak berpengaruh terhadap kepatuhan wajib pajak, sedangkan Tarif pajak, Kualitas Pelayanan dan Sanksi Perpajakan berpengaruh terhadap kepatuhan wajib pajak.
\end{abstract}

Kata kunci: Pemahaman, tarif pajak, kualitas pelayanan, kesadaran perpajakan, sanksi perpajakan, kepatuhan wajib pajak

\section{ABSTRACT}

This study aimed to analyze the influence of the understanding, the tax rate, quality of service, awareness of taxation, tax penalties on tax compliance in paying car tax with the application of progressive tax in the city of Surakarta. This study uses a survey approach field (field research) through questionnaires convey to taxpayers car in Surakarta. Respondents are taxpayers who pay motor vehicle tax in SAMSAT Surakarta. The sampling is compulsory car tax imposed progressive tax rates. The sampling technique using random sampling with a sample of 30 respondents. Methods of data analysis using multiple linear regression test. These results indicate that: Understanding and Awareness of taxation no effect on tax compliance, while the tax rate, Quality of Service and Sanctions Tax effect on tax compliance.

Keywords: Understanding, tax rates, quality of service, awareness of taxation, tax penalties, tax compliance 


\section{PENDAHULUAN}

Pajak merupakan salah satu sumber penerimaan negara yang sangat penting selain penerimaan lainnya yaitu penerimaan migas maupun penerimaan bukan pajak. Pemerintah berupaya secara terus menerus untuk meningkatkan target penerimaan negara dari sektor pajak.Pajak merupakan kontribusi wajib kepada negara yang terutang oleh orang pribadi atau badan yang bersifat memaksa berdasarkan Undang-Undang, dengan tidak mendapatkan imbalan secara langsung dan digunakan untuk keperluan daerah bagi sebesar-besarnya kemakmuran rakyat (UU No. 28 Tahun 2009).

Penerapan pajak progresif di Indonesia terdapat dua jenis, yaitu Pajak Penghasilan $(\mathrm{PPh})$ dan Pajak Kendaraan Bermotor (PKB). Pajak Progresif adalah pajak yang sistem pemungutannya dengan cara menaikkan persentase kena pajak yang harus dibayar sesuai dengan kenaikan objek pajak. Hal tersebut menyebabkan tarif pemungutan pajak akan semakin meningkat apabila jumlah atau kuantitas objek pajak semakin banyak dan jika nilai objek pajak mengalami kenaikan.

Undang-undang No.28 Tahun 2009 tentang Pajak Daerah dan Retribusi Daerah, tarif Pajak Kendaraan Bermotor Pribadi dikenakan secara progresif, yaituuntuk kepemilikan kendaraan bermotor pertama sebesar 1-2\% dan untuk kepemilikan kendaraan bermotor kedua dan seterusnya paling rendah sebesar $2 \%$ dan paling tinggi $10 \%$.

Setelah diberlakukannya tarif pajak progresif jumlah wajib pajak kendaraan bermotor semakin bertambah. Melihat realita ini diharapkan bisa memaksimalkan penerimaan pendapatan pemerintah yang bersumber dari pajak kendaraan bermotorsejalan dengan bertambahnya jumlah wajib pajak kendaraan bermotor.Tentunya banyak hal yang mempengaruhi hal tersebut. Salah satu hal yang mempengaruhi wajib pajak dalam melaksanakan kewajibannya sebagai warga Negara yang baik adalah kepatuhan dalam membayar pajak.Semakin tinggi kepatuhan wajib pajak, maka penerimaan pajak akan semakin meningkat,demikian pula sebaliknya (Lestari, 2016)

Kepatuhan wajib pajak yaitu dimana wajib pajak memenuhi kewajiban perpajakannya dan melaksanakan hak perpajakan dengan baik dan benar sesuai dengan peraturan dan undang-undang pajak yang berlaku. Salah satu upaya dalam meningkatkan kepatuhan wajib pajak yaitu memberikan pelayanan yang baik kepada wajib pajak. Adapun prasangka buruk sebagian besar masyarakat terhadap petugas pajak harus dirubah menjadi prasangka baik,untuk merubah hal tersebut tentu harus menciptakan dan meningkatkan pelayanan yang berkualitas . Dengan peningkatan kualitas pelayanan yang baik diharapkan dapat meningkatkan kepatuhan dalam bidang perpajakan. Karena Masyarakat akan membayar pajak apabila mereka merasakan pelayanan publik sebanding dengan pembayaran pajaknya.

Faktor-faktor yang mempengaruhi kepatuan wajib pajak dalam membayar pajak kendaraan bermotor selain kualitas pelayanan yaitu pemahaman sistem pemungutan pajak, tarif perpajakan, kesadaran perpajakan dan sanksi perpajakan. Pemahaman sistem perpajakan yang dimiliki oleh wajib pajak sangat penting karena dengan pemahaman tersebut akan meningkatkan kesadaran wajib pajak. Kesadaran perpajakan adalah kerelaan memenuhi kewajiban dan memberikan kontribusi kepada negara yang menunjang pembangunan negara. Kesadaran wajib pajak berkonsekuensi logis untuk wajib pajak, yaitu kerelaan wajib pajak memberikan kontribusi dana untuk pelaksaan fungsi perpajakan dengan cara membayar pajak tepat waktu dan tepat jumlah.

Penegakan hukum dalam pajak kendaraan bermotor diwujudkan melalui pemberian sanksi yaitu berupa pengenaan sanksi administrasi bagi pelanggar pajak. 
Adapun pemberian sanksi kepada wajib pajak yang tidak melakukan pembayaran sesuai jatuh tempo yang terdapat pada Surat Ketetapan Pajak Daerah (SKPD).Dengan demikian diharapkan agar peraturan perpajakan dipatuhi oleh wajib pajak.Pemberlakuan sanksi perpajakan diharapkan sebagai pencegah ketidakpatuhan dalam membayar pajak, di sisi lain sanksi berupa denda menghasilkan pendapatan, namun secara umum pelaksanaan sanksi perpajakan diharapkan menjadi keberhasilan pendapatan negara dari sektor pajak.

Penelitian ini merupakan replikasi dari penelitian Sari dan Susanti (2014) mengenai faktor-faktor yang mempengaruhi kepatuhan wajib pajak dalam membayar pajak kendaraan bermotor (PKB) di Unit Pelayanan Pendapatan Provinsi (UPPP) Kabupaten Seluma. Namun, penelitian ini memiliki perbedaan yang mendasar dari penelitian Sari dan Susanti yaitu variabel bebas yang diteliti ditambah tarif pajak dan kesadaran perpajakan, selain itu peneliti hanya meneliti wajib pajak kendaraan bermotor roda empat di Kota Surakarta.

Berdasarkan latar belakang masalah di atas maka, dalam penelitian ini akan diungkap penelitian dengan judul penelitian "FaktorFaktor Yang Mempengaruhi Kepatuhan Wajib Pajak Dalam Membayar Pajak Mobil Dengan Diberlakukannya Pajak Progresif Di Kota Surakarta”.

\section{METODE PENELITIAN}

Penelitian ini merupakan penelitian kuantitatif asosiatif, yaitupenelitian yang bertujuan untuk mengetahui hubungan dua variabel atau lebih (Sugiyono, 2014).Penelitian ini menggunakan pendekatan survey lapangan (field research) melalui kuesioner yang di sampaikan kepada wajib pajak mobil di Kota Surakarta.

Responden penelitian adalah wajib pajak mobil yang membayarkan pajak di SAMSAT Surakarta. Sumber data yang digunakan adalah data primer dengan menggunakan metode survey melalui kuesioner. Teknik pengambilan sampel menggunakan Random Sampling dengan sampel sebanyak 30 responden

Metode analisis data meliputi: uji instrumen penelitian berupa uji validitas dan reliabilitas, uji asumsi klasik berupa uji normalitas, uji multikolinearitas, uji heteroskedastisitas, serta uji hipotesis berupa uji regresi linear berganda, uji $F$, uji $t$ dan uji koefisien determinasi.

\section{HASIL DAN PEMBAHASAN}

Hasil perhitungan dengan IBM SPSS 19 diperoleh hasil analisis data meliputi: uji deskriptif data penelitian, uji instrument penelitian, uji asumsi klasik dan uji hipotesis.

\section{Hasil Uji Deskriptif Data Penelitian}

Tabel 1

Deskriptif Data Penelitian

\begin{tabular}{lcccc}
\hline \multicolumn{1}{c}{ Variabel Penelitian } & Minimum & Maksimum & Rerata & Penyimpangan Baku \\
\hline Pemahaman & 12 & 20 & 15,57 & 1,654 \\
Tarif Pajak & 15 & 22 & 17,37 & 1,771 \\
Kualitas Pelayanan & 11 & 18 & 14,93 & 2,333 \\
Kesadaran Perpajakan & 14 & 21 & 17,60 & 1,812 \\
Sanksi Perpajakan & 11 & 18 & 14,57 & 2,112 \\
Kepatuhan Membayar Pajak & 15 & 22 & 18,77 & 1,995 \\
\hline
\end{tabular}

Tabel 1 di atas menunjukkan pada variabel pemahaman tentang sistem perpajakan diperoleh nilai minimum 12 , nilai maksimum 20, nilai rerata 15,57 dan penyimpangan baku 1,654, variabel tarif pajak diperoleh nilai minimum 15 , nilai maksimum 22, nilai rerata 17,37 dan penyimpangan baku 1,771, variabel kualitas pelayanan diperoleh nilai minimum 11 , nilai maksimum 18, nilai rerata 14,93 dan penyimpangan baku 2,333, variabel kesadaran perpajakan diperoleh nilai 
minimum 14 , nilai maksimum 21 , nilai rerata 17,60 dan penyimpangan baku 1,812, variabel sanksi perpajakan diperoleh nilai minimum 11 , nilai maksimum 18 , nilai rerata 14,57 dan penyimpangan baku 2,112, dan variabel kepatuhan membayar pajak diperoleh nilai minimum 15 , nilai maksimum 22 , nilai rerata 18,77 dan penyimpangan baku 1,995 .

\section{Hasil Uji Instrumen Penelitian}

Tabel 2

Hasil Uji Validitas

\begin{tabular}{crrl}
\hline ButirPernyataan & $\mathrm{r}_{\text {hitung }}$ & $\mathrm{r}_{\text {tabel }}$ & Keterangan \\
\hline Pemahaman & & & \\
X1_1 & 0,788 & 0,361 & Butir pernyataan valid \\
X1_2 & 0,710 & 0,361 & Butir pernyataan valid \\
X1_3 & 0,899 & 0,361 & Butir pernyataan valid \\
X1_4 & 0,596 & 0,361 & Butir pernyataan valid \\
TarifPajak & & & \\
X2_1 & 0,480 & 0,361 & Butir pernyataan valid \\
X2_2 & 0,687 & 0,361 & Butir pernyataan valid \\
X2_3 & 0,743 & 0,361 & Butir pernyataan valid \\
X2_4 & 0,707 & 0,361 & Butir pernyataan valid \\
X2_5 & 0,827 & 0,361 & Butir pernyataan valid \\
KualitasPelayanan & & & \\
X3_1 & 0,778 & 0,361 & Butir pernyataan valid \\
X3_2 & 0,700 & 0,361 & Butir pernyataan valid \\
X3_3 & 0,869 & 0,361 & Butir pernyataan valid \\
X3_4 & 0,777 & 0,361 & Butir pernyataan valid \\
KesadaranPerpajakan & & & \\
X4_1 & 0,432 & 0,361 & Butir pernyataan valid \\
X4_2 & 0,792 & 0,361 & Butir pernyataan valid \\
X4_3 & 0,702 & 0,361 & Butir pernyataan valid \\
X4_4 & 0,687 & 0,361 & Butir pernyataan valid \\
X4_5 & 0,761 & 0,361 & Butir pernyataan valid \\
SanksiPerpajakan & & & \\
X5_1 & 0,749 & 0,361 & Butir pernyataan valid \\
X5_2 & 0,821 & 0,361 & Butir pernyataan valid \\
X5_3 & 0,755 & 0,361 & Butir pernyataan valid \\
X5_4 & 0,836 & 0,361 & Butir pernyataan valid \\
Kepatuhan Wajib Pajak & & & \\
Y_1 & 0,668 & 0,361 & Butir pernyataan valid \\
Y_2 & 0,582 & 0,361 & Butir pernyataan valid \\
Y_3 & 0,798 & 0,361 & Butir pernyataan valid \\
Y_4 & 0,833 & 0,361 & Butir pernyataan valid \\
Y_5 & 0,511 & 0,361 & Butir pernyataan valid \\
\hline & & &
\end{tabular}

Tabel 2 diatas, menunjukan bahwa semua butir pertanyaan variabel penelitian, yang terdiri variabel pemahaman, tarif pajak, kualitas pelayanan, kesadaran perpajakan, sanksi perpajakan dan kepatuhan membayar pajak dinyatakan valid, dibuktikan dengan diperolehnya semua nilai $r_{\text {hitung }}>r_{\text {tabel }}$. 
Tabel 3

Hasil Uji Reliabilitas

\begin{tabular}{lccc}
\hline \multicolumn{1}{c}{ Variabel } & Koef. Alpha & Critical Value & Keterangan \\
Pemahaman & 0,748 & 0,60 & Reliabel \\
\hline Tarif Pajak & 0,717 & 0,60 & Reliabel \\
Kualitas Pelayanan & 0,771 & 0,60 & Reliabel \\
Kesadaran Perpajakan & 0,712 & 0,60 & Reliabel \\
Sanksi Perpajakan & 0,798 & 0,60 & Reliabel \\
Kepatuhan Membayar Pajak & 0,713 & 0,60 & Reliabel \\
\hline
\end{tabular}

Tabel 3 diatas menunjukkan bahwa reliabilitas masing-masing variabel menunjukkan angka yang lebih besar dari 0,60 maka kuesioner dinyatakan reliabel atau handal. Kuesioner reliabel menandakan jawaban responden cenderung konsisten, jika ada peneliti lain mengulangi atau mereplikasi maka menghasilkan data yang sama.

\section{Uji Asumsi Klasik}

Tabel 4

Hasil Uji Normalitas

\begin{tabular}{lccc}
\hline \multicolumn{1}{c}{ Variabel } & $\begin{array}{c}\text { Sig. (2 } \\
\text { tailed) }\end{array}$ & Standar & Keterangan \\
\hline Pemahaman & 0,414 & 0,05 & Data Terdistribusi Normal \\
& 0,211 & 0,05 & Data Terdistribusi Normal \\
Tarif pajak & 0,549 & 0,05 & Data Terdistribusi Normal \\
$\begin{array}{l}\text { Kualitas prpjkn } \\
\text { Kesadaran } \\
\text { prpjkn }\end{array}$ & 0,402 & 0,05 & Data Terdistribusi Normal \\
$\begin{array}{l}\text { Sanksi prpjkn } \\
\text { Kepatuhan WP }\end{array}$ & 0,334 & 0,05 & Data Terdistribusi Normal \\
& 0,361 & 0,05 & Data Terdistribusi Normal
\end{tabular}

Tabel 4 di atas menunjukkan diperolehnya nilai Kolmogorov-Smirnov $\mathrm{Z}$ adalah sebesar 0,726 dan nilai signifikansi sebesar 0,665. Oleh karena itu karena diperoleh nilai signifikansi > 0,05 maka data penelitian berdistribusi normal.

Tabel 5

Hasil Uji Multikolinearitas

\begin{tabular}{lcrccc}
\hline \multicolumn{1}{c}{ Variabel Penelitian } & TOL & Cutoff & VIF & Cutoff & Keterangan \\
\hline Pemahaman & 0,489 & 0,10 & 2,044 & 10 & Tidak terjadi multikolinearitas \\
Tarif Pajak & 0,698 & 0,10 & 1,432 & 10 & Tidak terjadi multikolinearitas \\
Kualitas Pelayanan & 0,665 & 0,10 & 1,504 & 10 & Tidak terjadi multikolinearitas \\
Kesadaran Perpajakan & 0,644 & 0,10 & 1,552 & 10 & Tidak terjadi multikolinearitas \\
Sanksi Perpajakan & 0,565 & 0,10 & 1,770 & 10 & Tidak terjadi multikolinearitas \\
\hline
\end{tabular}

Tabel 5 di atas menunjukkan semua ditemukan adanya korelasi antar variabel nilai tolerance variabel bebas $>0,10$ dan bebas atau tidak terjadi multikolinearitas. semua nilai VIF $<10$, sehingga dapat disimpulkan dalam model regresi tidak 
Tabel 6

Hasil Uji Heteroskedastisitas

\begin{tabular}{lrll}
\hline \multicolumn{1}{c}{ Variabel Penelitian } & Standar & Sig. & Keterangan \\
\hline Pemahaman & 0,05 & 0,151 Tidak terjadi heteroskedastisitas \\
Tarif Pajak & 0,05 & 0,159 Tidak terjadi heteroskedastisitas \\
Kualitas Pelayanan & 0,05 & 0,262 & Tidak terjadi heteroskedastisitas \\
Kesadaran Perpajakan & 0,05 & 0,320 Tidak terjadi heteroskedastisitas \\
Sanksi Perpajakan & 0,05 & 0,946 Tidak terjadi heteroskedastisitas \\
\hline
\end{tabular}

Tabel 6 di atas menunjukkan bahwa semua nilai $t_{\text {hitung }}<t_{\text {tabel }}$ dan didukung oleh regresi memenuhi asumsi tidak terjadi semua nilai signifikansi $>0,05$, maka model permasalahan heteroskedastisitas.

\section{Uji Regresi Linear Berganda}

Tabel 7

Model Regresi Berganda

\begin{tabular}{lc}
\hline \multicolumn{1}{c}{ Parameter } & $\begin{array}{c}\text { Unstandardized } \\
\text { Coefficientsz }\end{array}$ \\
\hline Konstanta & 1,583 \\
Pemahaman & 0,070 \\
Tarif Pajak & 0,342 \\
Kualitas Pelayanan & 0,264 \\
Kesadaran Perpajakan & 0,078 \\
Sanksi Perpajakan & 0,331 \\
\hline
\end{tabular}

a. Model Regresi

Digunakan untuk mengetahui pengaruh antara lebih dari satu variabel bebas terhadap variabel terikat. Tabel $7 \mathrm{di}$ atas dapat disusun persamaan regresi linear berganda sebagai berikut:

$\mathrm{Y}=1,589+0,070 \mathrm{X}_{1}+0,342 \mathrm{X} 2+0,264 \mathrm{X}_{3}$ $+0,078 \mathrm{X}_{4}+0,331 \mathrm{X}_{5}+\mathrm{e}$

Interpretasi:

1) Nilai konstanta bernilai positif sebesar 1,589, hal ini menunjukkan bahwa apabila pemahaman, tarif pajak, kualitas pelayanan, kesadaran perpajakan, dan sanksi perpajakan bernilai konstan (0), maka kepatuhan membayar pajak sebesar 1,589.

2) Koefisien regresi pemahaman $\left(b_{1}\right)$ bernilai positif sebesar 0,070 . Hal ini berarti jika pemahaman tentang sistem perpajakan ditingkatkan satu satuan, maka meningkatkan kepatuhan membayar pajak sebesar 0,070, dengan asumsi variabel tarif pajak, kualitas pelayanan, kesadaran perpajakan, sanksi perpajakan bernilai konstan (0).

3) Koefisien regresi tarif pajak $\left(b_{2}\right)$ bernilai positif sebesar 0,342 . Hal ini berarti jika tarif pajak ditingkatkan satu satuan, maka meningkatkan kepatuhan membayar pajak sebesar 0,342, dengan asumsi variabel pemahaman, kualitas pelayanan, kesadaran perpajakan, sanksi perpajakan bernilai konstan (0).

4) Koefisien regresi kualitas pelayanan $\left(b_{3}\right)$ bernilai positif sebesar 0,264 . Hal ini berarti jika kualitas pelayanan ditingkatkan satu satuan, maka meningkatkan kepatuhan membayar pajak sebesar 0,264, dengan asumsi variabel pemahaman, tarif pajak, 
kesadaran perpajakan, sanksi perpajakan bernilai konstan (0).

5) Koefisien regresi kesadaran perpajakan $\left(b_{4}\right)$ bernilai positif sebesar 0,078. Hal ini berarti jika kesadaran perpajakan ditingkatkan satu satuan, maka meningkatkan kepatuhan membayar pajak sebesar 0,264, dengan asumsi variabel pemahaman, tarif pajak, kualitas pelayanan, sanksi perpajakan bernilai konstan (0).

6) Koefisien regresi sanksi perpajakan $\left(b_{5}\right)$ bernilai positif sebesar 0,331 . Hal ini berarti jika sanksi perpajakan ditingkatkan satu satuan, maka meningkatkan kepatuhan membayar pajak sebesar 0,331, dengan asumsi variabel pemahaman, tarif pajak, kualitas pelayanan, kesadaran perpajakan bernilai konstan (0).

b. Uji Kelayakan Model (Uji F)

Uji $\mathrm{F}$ digunakan untuk mengetahui pengaruh semua variabel bebas yang terdapat di dalam model secara bersamasama terhadap variabel terikat

Tabel 8

Hasil Uji F

\begin{tabular}{ccccc}
\hline $\mathrm{F}_{\text {hitung }}$ & $\mathrm{F}_{\text {tabel }}$ & Sig & $\alpha$ & Keterangan \\
\hline 9,865 & 2,60 & 0,000 & 0,050 & Model layak digunakan \\
\hline
\end{tabular}

Hasil uji $\mathrm{F}$ diperolehnya nilai $\mathrm{F}_{\text {hitung }}$ $=9,865>\mathrm{F}_{\text {tabel }}=2,60$, dan didukung sig. $0,000<0,05$, sehingga $\mathrm{H} 0$ ditolak, maka ada pengaruh pemahaman, tarif pajak, kualitas pelayanan, kesadaran perpajakan, sanksi perpajakan secara bersama-sama terhadap kepatuhan membayar pajak

c. Uji Hipotesis (Uji T)
Uji t pada dasarnya menunjukkan seberapa jauh pengaruh suatu variabel penjelas atau independen secara individual dalam menerapkan variasi variabel dependen. Uji t menggunakan uji dua pihak (two tail test), digunakan apabila hipotesis nol (H0) berbunyi "sama dengan" dan hipotesis alternatif berbunyi "tidak sama dengan" (Sugiyono, 2014).

Tabel 9

Hasil Uji t

\begin{tabular}{lccccl}
\hline \multicolumn{1}{c}{ Parameter } & $\mathrm{t}_{\text {hitung }}$ & $\mathrm{t}_{\text {tabel }}$ & Sig. & $\alpha$ & Keterangan \\
\hline Pemahaman & 0,348 & 2,060 & 0,731 & 0,05 & Ditolak \\
Tarif Pajak & 2,176 & 2,060 & 0,040 & 0,05 & Diterima \\
Kualitas Pelayanan & 2,158 & 2,060 & 0,041 & 0,05 & Diterima \\
Kesadaran Perpajakan & 0,489 & 2,060 & 0,629 & 0,05 & Ditolak \\
Sanksi Perpajakan & 2,257 & 2,060 & 0,033 & 0,05 & Diterima \\
\hline
\end{tabular}

1) Pemahaman Berpengaruh Terhadap Kepatuhan Membayar Pajak Hasil uji $\mathrm{t}$ diperolehnya nilai $\mathrm{t}_{\text {hitung }}=$ $0,348<\mathrm{t}_{\text {tabel }}=2,060$ dan didukung nilai sig. $=0,731(0,348<2,060$ dan $0,731>0,05)$, maka $\mathrm{H}_{0}$ diterima, sehingga disimpulkan terdapat pengaruh yang signifikan secara individual pemahaman terhadap kepatuhan membayar pajak.

2) Pengaruh Tarif Pajak Terhadap Kepatuhan Membayar Pajak Hasil uji $\mathrm{t}$ diperolehnya nilai $\mathrm{t}_{\text {hitung }}=$ $2,176>\mathrm{t}_{\text {tabel }}=2,060$ dan didukung nilai sig. $=0,040(2,176>2,060$ dan $0,040<0,05)$, maka $\mathrm{H}_{0}$ ditolak, 
sehingga disimpulkan terdapat pengaruh yang signifikan secara individual tarifpajakterhadap kepatuhan membayar pajak.

3) Pengaruh Kualitas Pelayanan Terhadap Kepatuhan Membayar Pajak Hasil uji $\mathrm{t}$ diperolehnya nilai $\mathrm{t}_{\text {hitung }}=$ $2,158>\mathrm{t}_{\text {tabel }}=2,060$ dan didukung nilai sig. $=0,041(2,158>2,060$ dan $0,041<0,05)$, maka $\mathrm{H}_{0}$ ditolak, sehingga disimpulkan terdapat pengaruh yang signifikan secara individual kualitaspelayananterhadap kepatuhan membayar pajak.

3) Kesadaran Berpengaruh Terhadap Kepatuhan Membayar Pajak Hasil uji $\mathrm{t}$ diperolehnya nilai $\mathrm{t}_{\text {hitung }}=$ $0,489<\mathrm{t}_{\text {tabel }}=2,060$ dan didukung nilai sig. $=0,629(0,489<2,060$ dan $0,629>0,05)$, maka $\mathrm{H}_{0}$ diterima, sehingga disimpulkan terdapat pengaruh yang signifikan secara individual kesadaran terhadap kepatuhan membayar pajak.

5) Pengaruh Sanksi Perpajakan Terhadap Kepatuhan Membayar Pajak Hasil uji $\mathrm{t}$ diperolehnya nilai $\mathrm{t}_{\text {hitung }}=$ $2,257>\mathrm{t}_{\text {tabel }}=2,060$ dan didukung nilai sig. $=0,033(2,257>2,060$ dan $0,033<0,05)$, maka $\mathrm{H}_{0}$ ditolak, sehingga disimpulkan terdapat pengaruh yang signifikan secara individual sanksi perpajakan terhadap kepatuhan membayar pajak.

\section{d. Uji Koefisien Determinasi}

Digunakan untuk mengukur seberapa jauh kemampuan model dalam menerangkan variasi variabel dependen.

Tabel 10

Hasil R Square

\begin{tabular}{ccccc}
\hline $\mathrm{R}$ & $\mathrm{R}$ Square & $\begin{array}{c}\text { Adjusted } \\
\text { R Square }\end{array}$ & Sisanya & Keterangan \\
\hline 0,820 & 0,673 & 0,604 & 0,396 & $\begin{array}{l}\text { Variasi variabel independen berpengaruh } \\
\text { sebesar } 0,604 \text { atau } 60,4 \%\end{array}$ \\
\hline
\end{tabular}

Hasil perhitungan dengan bantuan diperoleh nilai koefisien determinasi $\mathrm{R}$ Square sebesar 0,673 atau lebih tepatnya melihat nilai Adjusted R Square sebesar 0,604 atau $60,4 \%$. Oleh karena itu kemampuan model dalam menerangkan variasi variabel dependen sebesar $60,4 \%$, masih ada $39,6 \%$ lagi variabel lain yang tidak masuk dalam model mempengaruhi variasi variabel dependen.

\section{PEMBAHASAN}

Pembahasan hasil penelitian ini ini difokuskan berdasarkan hasil analisis data penelitian yang telah dilakukan, meliputi:

1. Pengaruh Pemahaman terhadap Kepatuhan Wajib Pajak dalam Membayar Pajak Mobil setelah Diberlakukannya Pajak Progresif di Kota Surakarta

Sistem pemungutan pajak official assessment system yaitu suatu sistem pemungutan yang memberikan wewenang
Aplikasi Komputer IBM SPSS Statistic 19, kepada pemerintah (fiskus) untuk menentukan besarnya pajak yang terutang oleh wajib pajak. Pemahaman wajib pajak tentang sistem perpajakan mempengaruhi kepatuhan wajib pajak dalam membayar pajak.

Hasil perhitungan diperoleh nilai $\mathrm{t}_{\text {hitung }}=0,348$ dan nilai sig. $=0,731$, maka $\mathrm{H}_{0}$ diterima dan $\mathrm{H}_{1}$ ditolak. Hal ini dapat disimpulkan bahwa pemahaman tentang sistem perpajakan tidak berpengaruh terhadap kepatuhan membayar pajak mobil setelah diberlakukannya pajak progresif di kota Surakarta.

Hasil penelitian ini relevan dengan penelitian Azizah danNurlaela (2016), dimana menemukan pemahaman tentang peraturan perpajakan tidak berpengaruh signifikan terhadap kemauan wajib pajak dalam membayar pajak orang pribadi. Namun, di sisi lain penelitian ini tidak 
relevan dengan penelitian Sari dan Susanti (2014), Ilhamsyah, dkk (2016) yang menemukan pemahaman tentang system perpajakan berpengaruh signifikan terhadap kepatuhan wajib pajak dalam membayar pajak.

2. Pengaruh Tarif Pajak terhadap Kepatuhan Wajib Pajak dalam Membayar Pajak Mobil setelah Diberlakukannya Pajak Progresif di Kota Surakarta

Tarif pajak merupakan prosentase perhitungan yang harus dibayar oleh wajib pajak. Penentuan mengenai pajak yang terutang sangat ditentukan oleh tarif pajak. Dalam penghitungan pajak yang terutang digunakan tarif pajak yang kemudian dikalikan dengan dasar pengenaan pajak. Penentuan mengenai pajak yang terutang ditentukan oleh tarif pajak dari berbagai jenis pajak, baik dari pajak pusat maupun pajak daerah.

Hasil perhitungan diperoleh nilai $\mathrm{t}_{\text {hitung }}=2,176$ dan nilai sig. $=0,041$, maka $\mathrm{H}_{0}$ ditolak dan $\mathrm{H}_{2}$ diterima. Hal ini dapat disimpulkan bahwa tarif pajak berpengaruh terhadap kepatuhan membayar pajak mobil setelah diberlakukannya pajak progresif di kota Surakarta.

Hasil penelitian ini tidak relevan dengan penelitian Suhendri (2015), dimana menemukan tarif pajak tidak berpengaruh signifikan terhadap kepatuhan membayar pajak.

3. Pengaruh Kualitas Pelayanan terhadap Kepatuhan Wajib Pajak dalam Membayar Pajak Mobil setelah Diberlakukannya Pajak Progresif di Kota Surakarta

Pelayanan adalah aktivitas tambahan di luar tugas pokok (job description) yang diberikan kepada konsumen, pelanggan, nasabah, dan sebagainya serta dirasakan baik sebagai penghargaan maupun penghormatan. Kualitas pelayanan akan berbanding lurus terhadap minat wajib pajak untuk datang ke Kantor SAMSAT untuk membayar pajak. Kualitas yang baik tidak dipungkiri dapat mendorong minat wajib pajak untuk membayar pajak kendaraan bermotor mereka.

Hasil perhitungan diperoleh nilai $\mathrm{t}_{\text {hitung }}=2,158$ dan nilai sig. $=0,040$, maka $\mathrm{H}_{0}$ ditolak dan $\mathrm{H}_{3}$ diterima. Hal ini dapat disimpulkan bahwa kualitas pelayanan berpengaruh terhadap kepatuhan membayar pajak mobil setelah diberlakukannya pajak progresif di kota Surakarta.

Hasil penelitian ini relevan dengan penelitian Putri dan Jati (2012), Azizah dan Nurlaela (2016), dan Ilhamsyah, dkk (2016) yang menemukan kualitas pelayanan berpengaruh signifikan terhada kepatuhan wajib pajak dalam membayar pajak.

4. Pengaruh Kesadaran Perpajakan terhadap Kepatuhan Wajib Pajak dalam Membayar Pajak Mobil setelah Diberlakukannya Pajak Progresif di Kota Surakarta

Kesadaran perpajakan merupakan suatu kondisi dimana wajib pajak mengetahui, memahami dan melaksanakan ketentuan perpajakan dengan benar dan sukarela. Kerelaan dalam memenuhi kewajiban dan memberikan kontribusi kepada negara yang menunjang pembangunan negara. Kesadaran wajib pajak berkonsekuensi logis untuk wajib pajak, yaitu kerelaan wajib pajak memberikan kontribusi dana untuk pelaksanaan fungsi perpajakan dengan cara membayar pajak tepat waktu dan tepat jumlah.

Hasil perhitungan diperoleh nilai $\mathrm{t}_{\text {hitung }}=0,489$ dan nilai sig. $=0,629$, maka $\mathrm{H}_{0}$ diterima dan $\mathrm{H}_{4}$ ditolak. Hal ini dapat disimpulkan bahwa kesadaran perpajakan tidak berpengaruh terhadap kepatuhan membayar pajak mobil setelah diberlakukannya pajak progresif di kota Surakarta.

Hasil penelitian ini relevan dengan penelitian Putri dan Jati (2012), Azizah dan Nurlaela (2016), dan Ilhamsyah, dkk (2016) yang menemukan kesadaran perpajakan berpengaruh signifikan 
terhadap kepatuhan wajib pajak dalam membayar pajak.

5. Pengaruh Sanksi Perpajakan terhadap Kepatuhan Wajib Pajak dalam Membayar Pajak Mobil setelah Diberlakukannya Pajak Progresif di Kota Surakarta

Dalam undang-undang perpajakan dikenal dua macam sanksi, yaitu Sanksi Administrasi dan Sanksi Pidana. Ancaman terhadap pelanggaran suatu norma perpajakan ada yang diancam dengan sanksi administrasi saja, ada yang diancam dengan sanksi pidana saja, dan ada pula yang diancam dengan sanksi administrasi dan sanksi pidana. Sanksi perpajakan merupakan alat pencegah (preventive) agar wajib pajak tidak melanggar norma perpajakan. Sanksi menjadi sebuah jaminan bahwa wajib pajak tidak akan melalaikan dan tidak melaksanakan kewajibannya sebagai wajib pajak, dengan adanya sanksi yang memberi efek jera, kepatuhan wajib pajak semakin meningkat.

Hasil penelitian diperoleh nilai $t_{\text {hitung }}$ $=2,257$ dan nilai sig. $=0,033$, maka $\mathrm{H}_{0}$ ditolak dan $\mathrm{H}_{5}$ diterima. Hal ini dapat disimpulkan bahwa kualitas pelayanan berpengaruh terhadap kepatuhan membayar pajak mobil setelah diberlakukannya pajak progresif di kota Surakarta.

Hasil penelitian ini relevan dengan penelitian Putri dan Jati (2012), Azizah dan Nurlaela (2016), dan Ilhamsyah, dkk (2016) yang menemukan sanksi perpajakan berpengaruh signifikan terhadap kepatuhan wajib pajak dalam membayar pajak.

\section{KESIMPULAN DAN SARAN Kesimpulan}

1. Pemahaman tentang sistem perpajakan dan kesadaran perpajakan tidak berpengaruh terhadap kepatuhan wajib pajak dalam membayar pajak mobil setelah diberlakukannya pajak progresif.

2. Tarif pajak, kualitas pelayanan, dan sanksi perpajakan berpengaruh terhadap kepatuhan wajib pajak dalam membayar pajak mobil setelah diberlakukannya pajak progresif.

\section{Saran}

1. Menambahkan variabel lain seperti: kewajiban moral, tingkat pendidikan, tingkat penghasilan, jenis pekerjaan, tingkat kepercayaan, teknologi perpajakan, dan lain sebagainya pada variabel bebas, agar lebih mewakili variabel penelitian.

2. Menambahkan sampel penelitian, sehingga daya generalisasi penelitian lebih besar dan keterwakilan sampel terpenuhi.

\section{DAFTAR PUSTAKA}

Azizah, N Istiqomah., Nurlaela, S., \& Wijayanti, A. (2016). Faktor-Faktor Yang Mempengaruhi Kemauan Membayar Pajak Wajib Pajak Orang Pribadi Yang Melakukan Pekerjaan Bebas. Seminar Nasional IENACO_110 ISSN:2337-4349 Universitas Islam Batik Surakarta

Ghozali, Imam. 2012. Aplikasi Analisis Multivariate Dengan Program IBM SPSS 20. Edisi 6. Semarang: Badan Penerbit Universitas Diponegoro.

Ilhamsyah, I., Endang, M.G.W. dan Dewantara, R.Y. 2016. "Pengaruh Pemahaman dan Pengetahuan Wajib Pajak Tentang Peraturan Perpajakan, Kesadaran Wajib Pajak, Kualitas Pelayanan, dan Sanksi Perpajakan Terhadap Kepatuhan Wajib Pajak Kendaraan Bermotor (Studi SAMSAT Kota Malang)". Jurnal Perpajakan (JEJAK) Vol. 8 No. 12016.

Indriyani, M., Nurlaela, S., \& Masitoh, E. (2016). Pengaruh Keadilan,Sistem Perpajakan, Diskriminasi, Dan Kemungkinan Terdeteksinya 
Kecurangan Terhadap Persepsi Wajib Pajak Orang Pribadi Mengenai Perilaku Tax Evasion. Seminar Nasional IENACO_106 ISSN:2337-4349 Universitas Islam Batik Surakarta.

Mardiasmo. 2016. Perpajakan.Edisi Revisi.Yogyakarta: Andi.

Peraturan Daerah Propinsi Jawa Tengah Nomor 2 Tahun 2011 tentang Pajak Kendaraan Bermotor.

Prastiwi, A., Nurlaela, S., \& Chomsatu, Y. (2016). Pengaruh Pendapatan Asli Daerah Dana Perimbangan Dan Belanja Pegawai Terhadap Belanja Modal Pemerintah Kota Surakarta. Seminar Nasioanal IENACO_113 ISSN:23374349 Universitas Islam Batik Surakarta

Putri, Armanda R.S dan Jati, I Ketut. 2012. "Faktor-faktor Yang Mempengaruhi Kepatuhan Wajib Pajak Dalam Membayar Pajak Kendaraan Bermotor Di Denpasar". E.Journal Akuntansi. Vol. 2, No.3. Bali: Fakultas Ekonomi dan Bisnis Universitas Udayana.

Sari, Vivi Yulian dan Susanti, Neri. 2016. "Faktor-faktor yang Mempengaruhi Kepatuhan Wajib Pajak Dalam Membayar Pajak Kendaraan Bermotor (PKB) di Unit Pelayanan Pendapatan Provinsi (UPPP) Kabupaten Seluma". Ekombis Review. Vol. 2 No. 1.Jurnal Ilmiah Ekonomi dan Bisnis. Bengkulu: Program Studi Akuntansi. Universitas Dehasen Bengkulu.

Sugiyono. 2014. Metodologi Penelitian Kuantitatif. Edisi Revisi.Cetakan KeduaBandung: Alfabeta.

Undang-Undang Nomor 28 tahun 2009 tentang Pajak Daerah dan Retribusi Daerah. 